\title{
Effects of Macrophage Depletion on Peritoneal Inflammation in Swiss Mice, Edible Frogs and Goldfish*
}

\author{
Magdalena CHADZINSKA, Elzbieta KolACZKOWSKA, Anna SCISLOWSKA-CZARNECKA, \\ Nico VAN ROOIJEN, and Barbara PLYTYCZ
}

Accepted September 6, 2004

\begin{abstract}
Chadzinska M., KolaczKowska E., Scislowska-CZarnecka A., VAn RoolJen N., PLYTYCZ B. 2004. Effects of macrophage depletion on peritoneal inflammation in Swiss mice, edible frogs and goldfish. Folia biol. (Kraków) 52: 225-231.

SWISS mice, edible frogs and goldfish i.p. injected with zymosan ( $Z$ groups) develop peritoneal inflammation connected with a massive intraperitoneal accumulation of leukocytes, which is significantly diminished in mice and fish (but not frogs) by supplementation of zymosan with morphine (ZM groups). In order to check the putative role of resident peritoneal macrophages in morphine-modulated zymosan-induced peritonitis, some animals were depleted of resident macrophages by repeated i.p. injections of clodronate-liposomes (CL) followed by Z or ZM injection. In SWISS mice such CL-induced removal of Mac-3-positive cells (macrophages) resulted in an enhanced influx and prolonged accumulation of polymorphonuclear leukocytes (PMNs) in CL-Z and CL-ZM groups in comparison with their counterparts with intact macrophages. Nevertheless, supplementation of zymosan with morphine inhibited the early stages of peritonitis in CL-treated animals as it did in untreated mice. This indicates that intact peritoneal macrophages of SWISS mice are important for limiting PMN accumulation, perhaps mainly through the release of IL-10, but are not critical for the induction of anti-inflammatory effects of morphine during the early stages of peritonitis. Unexpectedly, macrophage depletion in CL-treated frogs and fish resulted in a lack of a typical peritonitis in both $\mathrm{Z}$ and $\mathrm{ZM}$ groups of these ectothermic animals.
\end{abstract}

Key words: Clodronate-liposomes, peritonitis, Rana esculenta, Carassius auratus, IL-10.

Magdalena CHADZINSKA, Elzbieta KolaCZKOWSKA, Anna SCISLOWSKA-CZARNECKA, Barbara PLYTYCZ, Department of Evolutionary Immunobiology, Institute of Zoology, Jagiellonian University, $R$. Ingardena 6, 30-060, Kraków, Poland.

E-mail: chadz@zuk.iz.uj.edu.pl

Nico VAN ROOIJEN, Department of Cell Biology and Immunology, Vrije University, Amsterdam,

The Netherlands.

Peritoneal inflammation is easily induced and followed in various vertebrates. Previously, its course was investigated in representatives of fish (CHADZINSKA et al. 1999; CHADZINSKA et al. 2000; GRUCA et al. 1996), anuran amphibians (KOLACZKOWSKA et al. 2000; MENASZEK et al. 1999), and in several strains of mice (KOLACZKOWSKA et al. 2001a; KOLACZKOWSKA et al. 2002; PLYTYCZ \& NATORSKA 2002; STANKIEWICZ et al. 2001). The course of peritonitis may be modulated by several endogenous and exogenous factors, such as season (MENASZEK et al. 1999), ambient temperature (MENASZEK et al. 1999), stress (CHADZINSKA et al. 2002; NATORSKA et al. 2001; SCISLOWSKA-CZARNECKA et al. 2004), and pharmacological factors, e.g. morphine (CHADZINSKA et al. 1999; CHADZINSKA et al. 2000; KOLACZKOWSKA et al. 2001a; PLYTYCZ \& NATORSKA 2002).

In a series of experiments on the modulatory effects of morphine in experimental peritonitis, animals were intraperitoneally injected with a single irritant (e.g. thioglycollate broth, sephadex or zymosan) or an irritant supplemented with morphine. Morphine co-injection significantly impaired peritonitis in the Atlantic salmon (CHADZINSKA et al. 1999), goldfish (CHADZINSKA et al. 2000), and several strains of mice $(\mathrm{C} 57 \mathrm{C} 3 \mathrm{H}, \mathrm{SWISS}, \mathrm{Balb} / \mathrm{c}$, C57BL/6, CB6) (CHADZINSKA et al. 1999; KOLACZKOWSKA et al. 2001a; PLYTYCZ \& NATORSKA 2002; NATORSKA \& PLYTYCZ 2004), but did not impair peritonitis in the CBA mouse strain (NATORSKA \& PLYTYCZ 2004) nor in frogs and

*Supported by the State Committee for Scientific Research (KBN), Project No. 6P04C 04721. 
toads (KOLACZKOWSKA et al. 2000). Morphineinsensitivity in amphibians may be connected with the presence of high levels of unique endogenous opiods, deltorphine and dermorphine in these animals (AMICHE et al. 2000). Overall, the results indicate that the anti-inflammatory effects of morphine are quite common but not universal in vertebrates. In some instances the lack of inhibitory effects may be due to an improper dose, route, or time of drug administration. Moreover, in all investigated murine strains morphine acts as an antinociceptive agent already at a low dose $(5 \mathrm{mg} / \mathrm{kg}$ b.w.), while its anti-inflammatory action is exerted only by a high dose $(20 \mathrm{mg} / \mathrm{kg}$ b.w.) (PLYTYCZ \& NATORSKA 2002; NATORSKA \& PLYTYCZ 2004).

Such dual effects of morphine can be useful during planned surgeries as several products of potentially dangerous inflammatory reaction may be detrimental for organisms (HARRIS et al. 2002; FEGER et al. 2002; MOLLNES et al. 2002). Therefore, knowledge concerning the cellular and molecular mechanisms of modulatory effects of morphine on local inflammatory processes can have practical implications.

Several approaches may be applied in order to infer the mechanisms by which morphine effects the course of experimental peritonitis, including models with animals depleted of particular cell types participating in the inflammatory process, e.g. mast cells and/or resident peritoneal macrophages (AJUEBOR et al. 1999; KOLACZKOWSKA et al. 2001a, b; KOLACZKOWSKA et al. 2002; STANKIEWICZ et al. 2001). Mast cell-knockout animals may be used for investigations on the role of mast cells in inflammatory processes (WBB6F1-W/W ${ }^{v}$ ) (KOLACZKOWSKA et al. 2001a, b; KOLACZKOWSKA et al. 2002). Animals pre-injected with a well-known mast cell degranulator, compound 48/80 (AJUEBOR et al. 1999; KOLACZKOWSKA et al. 2001a, b; KOLACZKOWSKA et al. 2002; STANKIEWICZ et al. 2001), may also be used. Such approaches have shown that a lack of mast cells significantly inhibited the early stages of peritonitis in WBB6F1-W/W $\mathrm{W}^{\mathrm{v}}$ and Balb/c mice induced by zymosan only (KOLACZKOWSKA et al. 2001a, b; KOLACZKOWSKA et al. 2002; STANKIEWICZ et al. 2001) or by zymosan supplemented with morphine (KOLACZKOWSKA et al. 2001a). It should be underlined that the effects of manipulation with mast cell numbers are strain specific. In particular, pre-treatment with the compound 48/80 has enhancing effects on the subsequent zymosaninduced peritonitis in SWISS mice while the same procedure is inhibitory in CBA mice (STANKIEWICZ et al. 2001). On the other hand, the abundance of peritoneal mast cells and their sensitivity to morphine-dependent degranulation in CBA mice seem to be responsible for the lack of anti- inflammatory effects of morphine on this strain of mice (in preparation).

A procedure commonly used for macrophage depletion is the injection of a liposome-encapsulated apoptosis-inducing drug, clodronate (CL) (AJUEBOR et al. 1999; ESPENES et al. 1997; KOLACZKOWSKA et al. 2002; MIKAMI et al. 2003; VAN ROOIJEN et al. 1996).

The aim of the present experiments was to investigate the effects of animal pre-treatment with clodronate-liposomes on the subsequent peritonitis induced by zymosan alone or zymosan supplemented with morphine in phylogenetically distant animals: SWISS mice, frogs, and fish. Macrophage depletion enhanced subsequent peritonitis in SWISS mice but abolished it completely in the frog and fish.

\section{Material and Methods}

\section{Animals}

Goldfish (Carassius auratus) and edible frogs (Rana esculenta) from commercial suppliers were kept in aquaria at room temperature. Body mass of the goldfish and frogs at the time of experiments were 10-20 $\mathrm{g}$ and 17-25 g, respectively.

Adult male SWISS mice, purchased from a commercial supplier (Breeding of Laboratory Animals, Collegium Medicum, Kraków, Poland), were kept in $20 \times 13 \times 18 \mathrm{~cm}$ cages (four mice per cage) in a room with controlled temperature $\left(22^{\circ} \mathrm{C}\right)$ and photoperiod (lights on 8:00-20:00). Food (standard mouse laboratory chow) and water were available ad libitum. Animals were 6-8 weeks of age (25-30 g body mass) at the beginning of investigations. The experiments were conducted according to license no. 16/OP/2001 from the Local Ethical Committee.

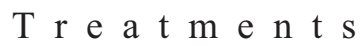

\section{Macrophage depletion}

Multilamellar liposomes containing clodronate (dichloromethylene diphosphonate, $\mathrm{Cl}_{2} \mathrm{MDP}$-liposomes, CL) and control PBS-containing liposomes (L) were prepared as described previously (VAN ROOIJEN \& SANDERS 1994). $\mathrm{Cl}_{2} \mathrm{MDP}$ was a gift of Roche Diagnostics GmbH, Mannheim, Germany. The animals were either untreated or i.p. injected with CL or L for three consecutive days, in a volume of $100 \mu \mathrm{l}$ for mice (according to AJUEBOR et al. 1999; KOLACZKOWSKA et al. 2002), $50 \mu \mathrm{l}$ for fish, and $200 \mu \mathrm{l}$ for frogs (on the basis of preliminary experiments on depletion of peritoneal macrophages). 
MOUSE
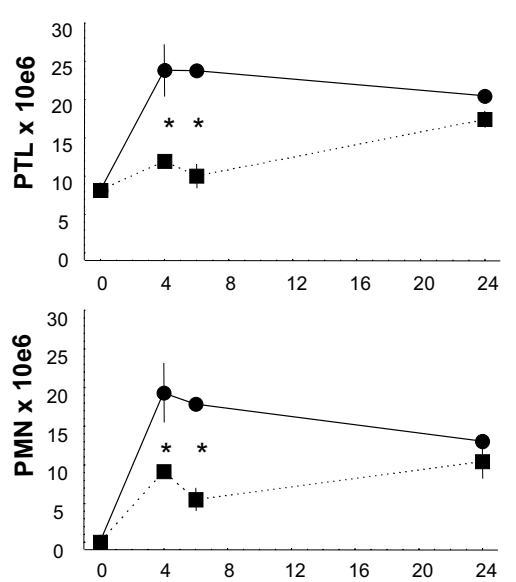

FROG

FISH
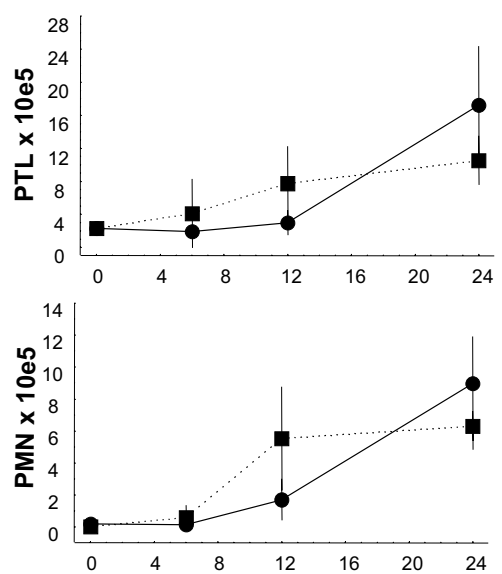
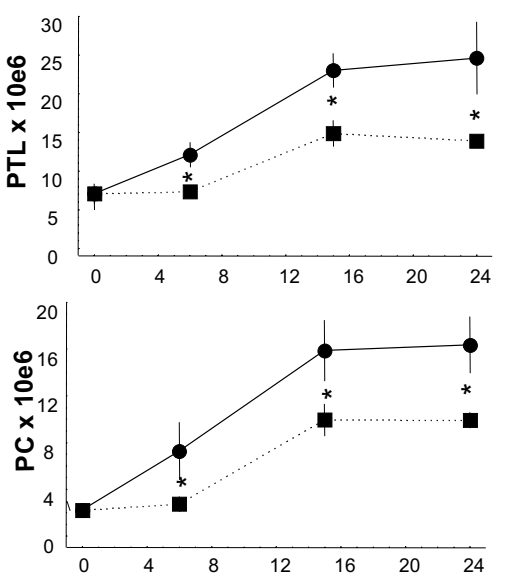

TIME AFTER INJECTION [h]

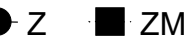

Fig. 1. Kinetics of peritonitis in SWISS mice, edible frogs (Rana esculenta) and goldfish (Carassius auratus) i.p. injected at time 0 with zymosan only $(Z)$ or zymosan supplemented with morphine $(Z M)$. $X_{ \pm} S E(n=4-8)$. Asterisks - statistically significant differences between $Z$ and $Z M$ values at $P<0.05$. Top: PTL - peritoneal leukocytes; Bottom: PMN polimorphonuclear leukocytes or PC - phagocytic cells.

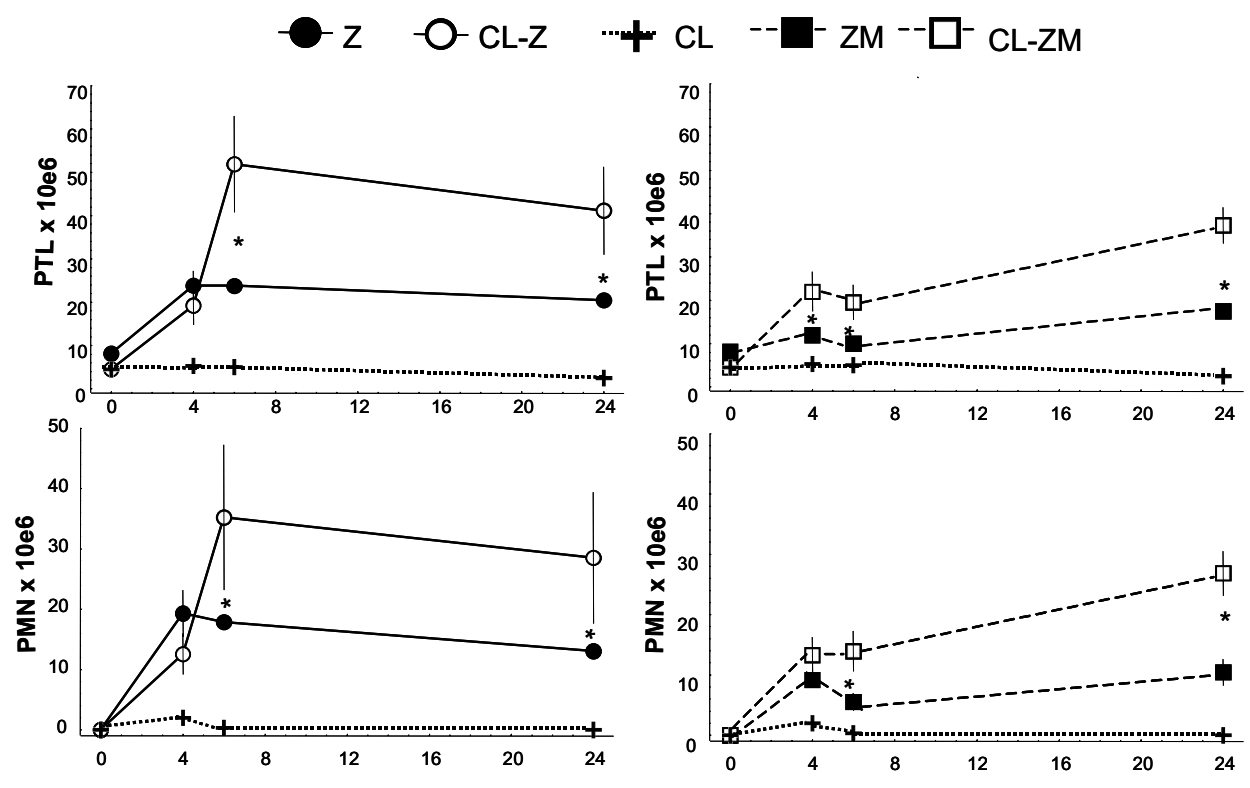

TIME AFTER INJECTION Thl

Fig. 2. Effects of macrophage depletion by clodronate-liposomes (CL) on kinetics of peritonitis in SWISS mice i.p. injected at time 0 with zymosan only $\left(Z-\right.$ left column) or zymosan supplemented with morphine $\left(Z M-\right.$ right column). $X_{ \pm} S E(n=4-8)$. Asterisks - statistically significant differences between Z/CL-Z and ZM/CL-ZM at $P<0.05$. PTL - peritoneal leukocytes; $\mathrm{PMN}$ - polimorphonuclear leukocytes.

\section{Induction of peritonitis}

Twenty-four hours after the last CL or L injection the animals were either left untreated or i.p. injected with freshly prepared zymosan ( $Z$ groups) (2 mg/ml, $0.5 \mathrm{ml} / 25 \mathrm{~g}$ b.w.) (Zymosan A, Sigma, St. Louis, MO, USA) in sterile PBS (220mOsM for frogs, $280 \mathrm{mOsM} /$ fish and $320 \mathrm{mOsM} / \mathrm{mice}$ ), or with zymosan supplemented with morphine hydrochloride (20mg/kg b.w.; ZM groups, Polfa, Kutno, Poland). Animals were killed at selected time points and their peritoneal cavities were lavaged with $1 \mathrm{ml}$ of PBS. Exudatory cells were Turk-stained and counted with a hemocytometer or on cytospin preparations stained with MGG. Peritoneal fluid was stored at $-20^{\circ} \mathrm{C}$ for future cytokine assays. 

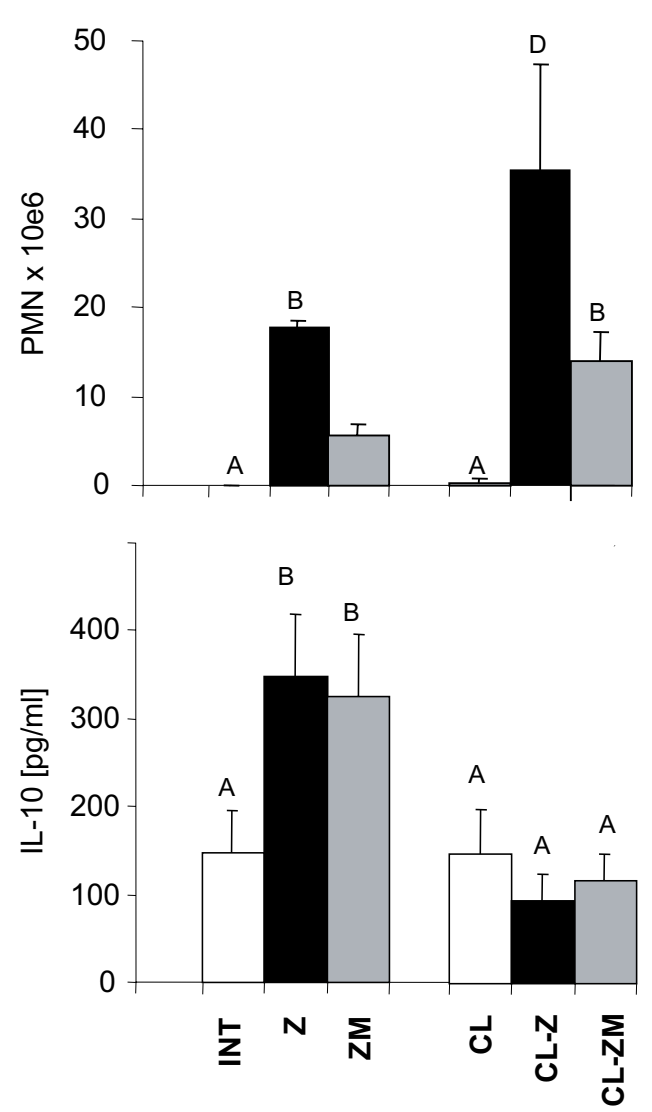

Fig. 3. Effects of macrophage depletion by clodronate liposomes (CL) on the number of exudatory polymorphonuclear leukocytes (PMNs) (top) and IL-10 polymorphonuclear leukocytes (PMNs) (top) and IL-10 inflammation induced by zymosan only $(Z)$ or zymosan supplemented with morphine (ZM). INT - intact animals. $\mathrm{X} \pm \mathrm{SE}(\mathrm{n}=4-8)$. Values with different letters $(A, B, C)$ vary significantly according to Tukey's test at $\mathrm{P}<0.05$.

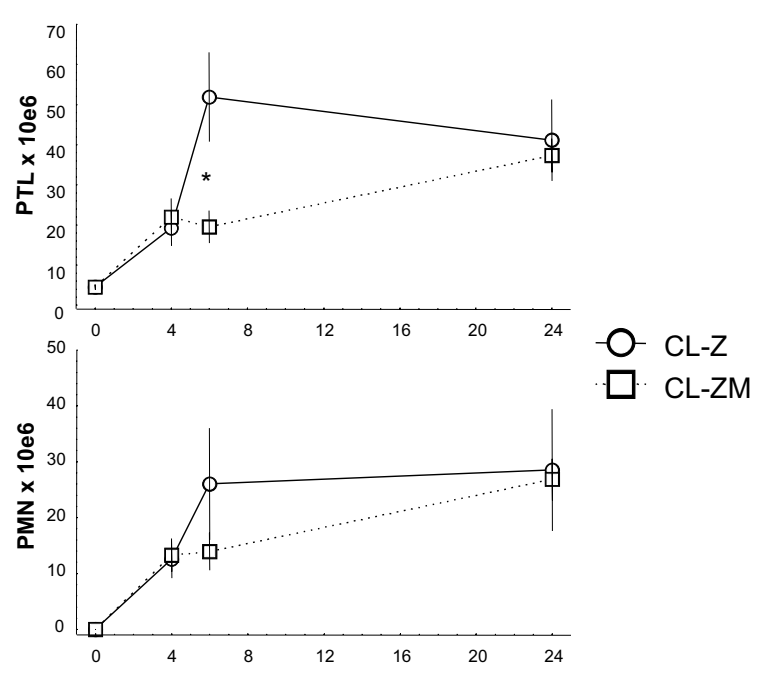

TIME AFTER INJECTION [h]

Fig. 4. Effects of morphine supplementation (ZM) on zymosan-induced peritonitis $(Z)$ in SWISS mice pre-treated with clodronate-liposomes (CL) for macrophage depletion. $\mathrm{X}_{ \pm} \mathrm{SE}(\mathrm{n}=4-8)$. Top: PTL - peritoneal leukocytes; Bottom: PMN - polimorphonuclear leukocytes; Asterisks - statistically significant differences between CL-Z and CL-ZM at $\mathrm{P}<0.05$.

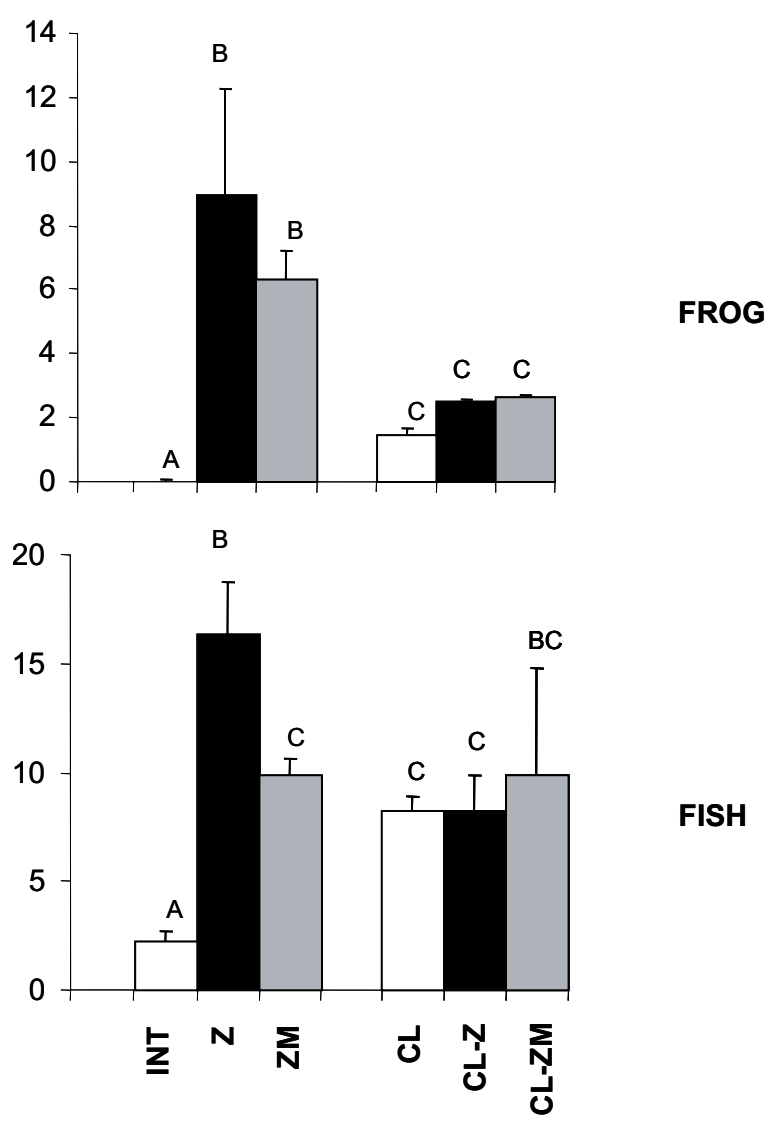

Fig. 5. Effects of macrophage depletion by clodronate liposomes (CL) on exudatory polimorphonuclear leukocytes (PMNs) in the edible frog Rana esculenta (top) and goldfish Carassius auratus (bottom) at 24 hours of peritoneal inflammation induced by zymosan only $(Z)$ or zymosan supplemented with morphine (ZM). INT - intact animals. $\mathrm{X} \pm \mathrm{SE}(\mathrm{n}=4-8)$. Values with different letters $(\mathrm{A}, \mathrm{B}, \mathrm{C})$ vary significantly according to Tukey's test at $\mathrm{P}<0.05$.

\section{Immunocytochemistry}

For macrophage identification, cytospin preparations were fixed with a methanol:acetone mixture $(1: 1)$, stored at $-20^{\circ} \mathrm{C}$ and treated with rat anti-mouse anti-Mac-3 monoclonal antibodies (Pharmingen, San Diego, USA) followed by mouse antirat biotin-conjugated anti-IgG1 secondary antibodies (Pharmingen, San Diego, USA). Thereafter, the preparations were incubated with a streptavidin-peroxidase complex (Pharmingen, San Diego, USA) and the products of reaction were visualised with 3',3'-diaminobenzidine tetrahydrochloride - DAB (ICN, Aurora, USA).

\section{IL-10 detection}

IL-10 levels were estimated by ELISA according to manufacturer instructions (BiouSource, Cammarillo, USA). 
$\mathrm{Stat}$ is t i c a 1 a n a 1 y s i s

The results were statistically analysed by ANOVA with a post hoc Tukey's test.

\section{Results and Discussion}

In all investigated species i.p. zymosan injection ( $\mathrm{Z}$ groups) induced peritoneal inflammation connected with intraperitoneal accumulation of exudatory leukocytes (Fig. 1, top). Among the total pool of peritoneal leukocytes (PTLs) of mice and frog, polymorphonuclear neutrophils (PMNs) were easy to distinguish and count both by hemocytometer and on cytospin preparations. They were apparently absent in intact animals and appeared quickly at the early stages of peritonitis (Fig. 1, bottom). In contrast, goldfish heterophiles can be distinguished only at the level of transmission electron microscopy (BIELEK et al. 1999), therefore for the present purpose they were pooled with macrophages as phagocytic cells (PCs) (Fig. 1, bottom right). Kinetics of the intraperitoneal accumulation of leukocytes were species-specific, but in each case the number of exudatory leukocytes that accumulated in the focus of inflammation 24 hours after injection was higher than that in the respective controls (time 0) (Fig. 1). Figure 1 also shows that the intraperitoneal influx of leukocytes, among them PMNs/PCs, was significantly impaired by morphine supplementation of the irritant in SWISS mice and goldfish, but not in the edible frogs. This fully confirms our previous results on zymosan-induced inflammation in SWISS mice (PLYTYCZ \& NATORSKA 2002), on thioglycollateinduced inflammation in the goldfish (CHADZINSKA et al. 2000), and sephadex-induced frog peritonitis (KOLACZKOWSKA et al. 2000).

Anti-inflammatory effects of morphine are antagonized by naltrexone and correspond to decreased levels of chemoattractants in the focus of inflammation and in blood (CHADZINSKA et al. 1999; CHADZINSKA et al. 2000). In the case of mice, morphine effects are achieved by a relatively high dose ( $20 \mathrm{mg} / \mathrm{kg} \mathrm{b.w.),} \mathrm{while} 5 \mathrm{mg} / \mathrm{kg}$ b.w. of morphine efficiently elicits the well-known antinociceptive effects of this drug. In our model of peritoneal inflammation, zymosan-induced pain is manifested by the characteristic body writhes that are completely attenuated in the animals coinjected with morphine (PLYTYCZ \& NATORSKA 2002; NATORSKA \& PLYTYCZ 2004).

At the early stages of zymosan-induced peritonitis, the intraperitoneal accumulation of endogenous opioids was recorded. These were derived from closely located lymph nodes and some brain areas (CHADZINSKA et al. 2003) and/or produced and released locally by inflammatory leukocytes (CHADZINSKA et al. 2001) as evidenced also in other models of inflammation (CABOT et al. 2001; RITTNER et al. 2001; PRZEWLOCKI et al. 1992). It seems that local administration of exogenous morphine may support or replace the anti-nociceptive action of endogenous opioids in the focus of inflammation and can limit the chemotactic influx/accumulation of new-coming leukocytes (PLYTYCZ $\&$ NATORSKA 2002).

In order to check the role of macrophages in morphine-modulated peritonitis, some animals were selectively depleted of peritoneal macrophages by a 3-day treatment with liposomes encapsulating the apoptosis-inducing clodronate (CL). On the $4^{\text {th }}$ day, animals were injected only with zymosan (CL-Z groups) or zymosan supplemented with morphine (CL-ZM groups). No differences were observed between animals treated with PBS-containing liposomes (L) and those left untreated. In the case of mice, an efficiency of clodronate-liposomes treatment in the removal of macrophages was evidenced by the lack of Mac3-positive cells in CL-treated groups, while they were numerous in the respective groups of animals untreated with CLs (data not shown).

Figure 2 shows that in SWISS mice an intraperitoneal influx and accumulation of PTLs (including PMNs) during the first 24 hours of inflammation was significantly higher in macrophage-depleted CL-Z and CL-ZM groups of animals than in the respective $Z$ and $Z M$ counterparts with the intact population of macrophages.

Figure 3 shows the PMN (top) and IL-10 (bottom) accumulation in exudatory fluid at the $6^{\text {th }}$ hour of peritonitis in SWISS mice with intact macrophages (left parts) and their CL-treated counterparts (right parts). The IL-10 is significantly elevated in $\mathrm{Z}$ and $\mathrm{ZM}$ groups of animals with intact macrophages, while it is at the control level in all CL-pretreated mice. The latter corresponds with a significant increase of PMNs in macrophage-depleted animals versus respective controls (CL-ZM versus ZM; CL-Z versus Z) (Fig. 3). Similar enhancement of PMN influx in macrophage-depleted SWISS mice, corresponding to a marked reduction of IL-10 levels in the lavage fluid, was described previously by AJUEBOR et al. (1999). Therefore our results confirmed the assumption that macrophage-derived IL-10 plays a pivotal role in a down-regulation of PMN accumulation in the focus of inflammation as its lack leads to enhanced accumulation of PMNs.

Interestingly, despite the macrophage depletion, morphine supplementation inhibited influx and prolonged local accumulation of leukocytes (in- 
cluding PMNs) in the focus of inflammation in CL-ZM versus CL-Z groups of animals (Fig. 4), in a manner similar to that in the animals with intact macrophages (compare Fig. 4 with the left panel of Fig. 1). Therefore it seems that intact macrophages are not critical for the development of inhibitory effects of morphine in the early stages of inflammation, at least in SWISS mice, whereas the role of mast cells may be more crucial (KOLACZKOWSKA et al. 2001a; STANKIEWICZ et al., in press).

Surprisingly, macrophage depletion in the goldfish and edible frogs resulted in a lack of inflammatory cell influx in CL-treated animals injected with $\mathrm{Z}$ or ZM. The results of experiments performed so far on fish and frogs depleted of macrophages are not conclusive. The CL-treatment alone induced a significant intraperitoneal accumulation of PMNs in the frog (Fig. 5, top) and phagocytes (perhaps heterophiles) in the goldfish (Fig. 5, bottom) when compared to the respective intact controls. In contrast to animals with intact macrophages, the number of peritoneal leukocytes in CL-treated frogs and fish was not further increased by injection with either Z or ZM (Fig. 5). It seems that in frogs and fish the clodronateliposomes themselves induced moderate but relatively long-lasting peritoneal inflammation with local accumulation of exudatory PMNs/heterophiles. It is known that in rodents CLs induce a minor inflammatory response that is quickly resolved and absent by day 4 when further experiments on macrophagedepleted animals are conducted (VAN ROOIJEN \& SANDERS 1994). In ectothermic vertebrates with a low metabolic rate, such CL-induced inflammation may last longer, thus the starting point for $\mathrm{Z}$ or ZM injections should be postponed. Nevertheless, the possibility that intact macrophages are crucial for the proper development of peritonitis in fish and frogs cannot be excluded at present.

\section{Acknowledgements}

We would like to acknowledge Joanna NATORSKA for performing immunocytochemical stainings.

\section{References}

AJUEBor M. N., DAS A. M., Virag L., Flower R. J., SZABo C., PerretTi M. 1999. Role of resident peritoneal macrophages and mast cells in chemokine production and neutrophil migration in acute inflammation: evidence for an inhibitory loop involving endogenous IL-10. J. Immunol. 162: 1685-1691.

Amiche M., SeOn A. A., Wroblewski H., Nicolas P. 2000. Isolation of dermatoxin from frog skin, an antibacterial peptide encoded by a novel member of the dermaseptin genes family. Eur. J. Biochem. 267: 4583-92.

BiElEK E., Bigaj J., ChadZINSKA M., PlytyCZ B. 1999. Depletion of head kidney neutrophils and cells with basophilic granules during peritoneal inflamation in the goldfish, Carassius auratus. Folia biol. (Kraków) 47: 33-42.

CABot P. J., Carter L., Schafer M., Stein C. 2001. Methionine-enkephalin- and dynorphin A-release from immune cells and control of inflammatory pain. Pain 93: 207-212.

Chadzinska M., KolaczKowsKa E., SElJElid R., PLYTYCZ B. 1999. Morphine modulation of peritoneal inflammation in Atlantic salmon and CB6 mice. J. Leukocyte Biol. 65: 590-596.

Chadzinska M., MaJ M., ScislowsKa-CZARnECKA A., PRZEWLOCKA B., PLYTYCZ B. 2001. Expresion of proenkephalin (PENK) mRNA in inflammatory leukocytes during experimental peritonitis in Swiss mice. Pol. J. Pharmacol. 53: 715-718.

CHADZINSKA M., SCISLOWSKA-CZARNECKA A., PIERZCHALA-KOZIEC K., PLYTYCZ B. 2003. Inflammation-induced alternations in local and central met-enkephalin in mice. Pol. J. Pharmacol. 55: 467-470.

Chadzinska M., Scislowska-CZARneCKa A., PlyTyCZ B. 2000. Inhibitory effects of morphine on some inflammation related parameters in the goldfish Carassius auratus L. Fish \& Shellfish Immunology 10: 531-542.

Chadzinska M., ScislowsKa-CZARneCKa A., PlyTyCZ B. 2002. Opposite effects of stress and dexamethasone on peritonitis in the goldfish. V Conference "Biologia molekularna w diagnostyce chorób zakaźnych i biotechnologii", SGGW, Warszawa 7 December 2002 Pp. 32-35.

ESPENES A., PRESS C. M., VAN ROOIJEN N. V., LANDSVERK T. 1997. Apoptosis in phagocytotic cells of lymphoid tissues in rainbow trout (Oncorhynchus mykiss) following administration of clodronate liposomes. Cell Tissue Res. 289: 323-331.

FEgER F., VARADARADJALOU S., GaO Z., ABRAHAM S. N., AROCK M. 2002. The role of mast cells in host defense and their subversion by bacterial pathogens. Trends Immunol. 23: $151-158$

GRUCA P., Chadzinska M., LaCKOWSKa B., PlytyCz B. 1996. Analysis of peritoneal and head kidney phagocytes during tioglycollate-elicited peritoneal inflammation in the goldfish, Carassius auratus. Folia biol. (Kraków) 44: 137-142.

HaRris S. G., PADilla J., Koumas L., RAY D., PhipPS R. P. 2002. Prostaglandins as modulators of immunity. Trends Immunol. 23: 144-150.

KolaczKowska E., Menaszek E., SelJelid R., Plytycz B. 2000. Experimental peritonitis amphibians is not suppressed by morphine treatment. Pol. J. Pharmacol. 52: 323-326.

KolaczKowsKa E., SElJelid R., PlyTyCZ B. 2001a. Critical role of mast cells in morphine-mediated impairment of zymosan-induced peritonitis in mice. Inflamm. Res. 50: 415-421.

KolaczKowsKa E., SElJELID R., PlytyCz B. 2001b. Role of mast cells in zymosan-induced peritoneal inlammation in $\mathrm{Balb} / \mathrm{c}$ and mast cell-deficient WBB6F1 mice. J. Leukocyte Biol. 69: 33-42.

Kolaczkowska E., Shahzidi S., Seljelid R., VAN ROOIJEN N., PLYTYCZ B. 2002. Early vascular permeability in murine experimental peritonitis is co-mediated by resident peritoneal macrophages and mast cells: crucial involvement of macrophage-derived cysteinyl-leukotrienes. Inflammation 26: 61-71.

Menaszek E., Miskiewicz K., Plytycz B. 1999. Comparative studies on experimental peritoneal inflammations in anuran amphibians. Central-Eur. J. Immunol. 24: 211-217.

MiKami Y., TAKeda K., ShibUYA K., QIU-FenG H., SHIMAMURA H., YAMAUCHI J., EGAWA S., SUNAMURA M., YAGI H., ENDO Y., MATSUNO S. 2003. Do peritoneal macrophages play an essential role in the progression of acute pancreatitis in rats? Pancreas 27: 253-260.

Mollnes T. E., SONG W.C., LAMBRIS J. D. 2002. Complement in inflammatory tissue damage and disease. Trends Immunol. 23: 61-64.

NATORSKA J., PLYTYCZ B. 2004. Strain specific dissociation in the modulatory effects of morphine on zymosan-induced peritoneal inflammation in mice. Submitted.

NATORSKA J., CHADZINSKA M., SCISLOWSKA-CZARNECKA A., PLYTYCZ B. 2001. Stress of saline injections or aseptic 
puncture modifies subsequent peritoneal inflammation. IV Conference „Biologia molekularna w diagnostyce chorób zakaźnych i biotechnologii”, SGGW, Warszawa 8 December 2001 Pp. 142-144.

PlyTYCZ B., NATORSKA J. 2002. Morphine attenuates pain and prevents inflammation in experimental peritonitis. Trends Immunol. 23: 340-341.

PrZeWlocki R., Hassan A. H., Lasoń W., EPPlen C., HERZ A., STEIN C. 1992. Gene expression and localization of opioid peptides in immune cells of inflamed tissue: functional role in antinociception. Neuroscience 48: 491-500.

RitTNeR H. L., BRACK A., MACHELSKA H., MOUSA S. A., BAUER M., SCHAFER M., STEIN C. 2001. Opioid peptideexpressing leukocytes. Anesthesiology 95: 500-5008.

SCISLOWSKA-CZARNeCKA A., ChADZINSKA M., PlyTYCZ B. 2004. Long-lasting effects of social stress on peritoneal inflammation in some strains of mice. Folia biol. (Kraków) 52: $97-104$.

STANKIEWICZ E., WyPASEK E., PlytyCZ B. 2001. Opposite effects of mast cell degranulation by compound 48/80 on peritoneal inflammation in Swiss and CBA mice. Pol. J. Pharmacol. 53: 149-155.

StANKIEWICZ E., WyPASEK E., PlytyCZ B. 2004. Mast cells are responsible for the black of anti-inflammatory effects of morphine in CBA mice. Med. Inflamm. (In press).

VAN ROOIJEN N., SANDERS A. 1994. Liposome mediated depletion of macrophages: mechanism of action, preparation of liposomes and applications. J. Immunol. Methods 174: 83-93.

VAN ROOIJEN N., SANDERS A., VAN DEN BERG T. K. 1996. Apoptosis of macrophages induced by liposome-mediated intracellular delivery of clodronate and propamidine. J. Immunol. Methods 193: 93-99. 